\title{
PENGARUH LAYANAN BIMBINGAN KELOMPOK DENGAN TEKNIK JOHARI WINDOW TERHADAP PENINGKATAN PEMAHAMAN DIRIREMAJA ISLAM MASJID
}

\author{
Edo Suhendi, Hadiwinarto, Rita Sinthia \\ Prodi Bimbingan dan Konseling Fakultas Keguruan dan Ilmu Pendidikan \\ Universitas Bengkulu \\ edosuhendi25@yahoo.com,Hadiwin@unib.co.id, Sinthia.rita@unib.co.id
}

\begin{abstract}
ABSTRAK
Penelitian ini bertujuan untuk mendeskripsikan pengaruh layanan bimbingan kelompok dengan teknik Johari Window terhadap peningkatan pemahaman diri remaja Islam masjid. Penelitian ini merupakanpenelitian eksperimen dengan desain penelitian one group pretest and posttest design. Subjek penelitian ini adalah 8 remaja Islam masjid Darul Hikmah. Teknik pengumpulan data dalam penelitian ini menggunakan tes pemahaman diri remaja. Hasil penelitian ini menunjukkan pemahaman remaja tentang pemahaman diri meningkat setelah diberikan layanan bimbingan kelompok dengan teknik Johari Window. Mean pre-test $=13,5$ dan mean post test $=20,13$ dengan nilai $\mathrm{t}=-11,121$ (Sig.<0,05). Berarti ada peningkatan pemahaman remaja tentang pemahaman diri remaja sesudah pemberian layanan bimbingan kelompok dengan teknik Johari Window.
\end{abstract}

Kata kunci : layanan bimbingan kelompok, johari window, pemahaman diri, remaja

\section{THE INFLUENCE OF GROUP GUIDANCE SERVICES WITH JOHARI WINDOW TECHNIQUES TO INCREASE SELF-UNDERSTANDING OF ADOLESCENT OFISLAM MOSQUE DARUL HIKMAH}

\begin{abstract}
This research aims to describe the influence of group guidance services withJohari Window techniques to increase self-understanding of adolescent of Islam mosque. This research was experimental which research design are one group pretest and posttest design. The Subject of this research were 8 adolescent Islam mosque Darul Hikmah. Technique of collecting data in this researched was test adolescent self-understanding. The result of this research showed adolescent understanding about self-understanding increased after giving group guidance service with technique Johari Window. Mean pre-test $=13,5$ and mean post test $=20,13$ with $\mathrm{t}=-11,121$ (Sig.<0,05). Means that there was enhancement adolescent understanding about adolescent self-understanding after giving group guidance service with technique Johari Window.
\end{abstract}

Keywords:group guidance service, johari window, self-understanding, adolescent 


\section{Pendahuluan}

Remaja merupakan aset penting negara untuk menjadi negara yang maju, dikarenakan generasi muda-lah yang akan menggantikan kedudukan pemimpin-pemimpin negara pada masa yang akan datang. Hal ini sangat di sayangkan melihat remaja-remaja pada zaman sekarang yang tidak peduli terhadap lingkungan sekitarnya dan hanya memikirkan dirinya sendiri tanpa adanya keinginan untuk berperan aktif dalam masyarakat di lingkungan sekitar tempat tinggalnya.Menurut Sarwono (2013:17) Remaja adalah suatu masa transisi dari masa anak ke dewasa, yang ditandai dengan perkembangan biologis, psikologis, moral, agama, kognitif dan sosial. Hal ini menunjukkan bahwa dimasa remaja, individu harus memiliki pemahaman diri yang baik untuk dapat mengaktualisasikan dirinya secara optimal dalam perkembangan fisik, psikis, sosial, dan moral. Pemahaman diri dapat mempermudah individu dalam menyelesaikan permasalahan yang dihadapinya sehingga dengan memahami diri yang baik akan menciptakan individu yang dapat berperilaku asertif pada dirinya maupun orang lain yang ada disekitarnya. Sukardi (1990:4) menyatakan bahwa pemahaman diri dapat diartikan sebagai suatu keadaan di mana individu dapat secara mandiri mengenal berbagai aspek mengenai dirinya dengan jelas secara nalar dan logis. Remaja akan terus menerus melakukan hal-hal yang merugikan dirinya maupun orang lain, apabila remaja tidak dapat memahami dirinya dengan baik sehingga hal tersebut akan membuat remaja mengalami kegagalan-kegagalan pada dirinya yang menyebabkannya menjadi tertekan.

Fenomena yang terjadi di lapangan menunjukkan bahwa pemahaman diri remaja Islam masjid Darul Hikmah di Kelurahan Cempaka Permai masih kurang baik. Hal ini terlihat dari sikap dan perilaku remaja Islam masjid Darul Hikmah ketika melakukan kegiatan tidak sesuai dengan apa yang seharusnya dilakukan, seperti : bermain game, membentuk kelompokkelompok kecil yang mengobrolkan hal-hal yang di luar kegiatan organisasi, tidak berperan aktif ketika melakukan kegiatan, saling bersikap egois satu sama lain, kurang menjaga kebersihan masjid dan merokok.

Pemahaman diri remaja dapat ditingkatkan melalui layanan bimbingan kelompok dengan teknik Johari Window. Layanan bimbingan kelompok dengan teknik Johari Window dipandang tepat dalam membantu remaja untuk memahami dirinya secara komprehensif. Layanan bimbingan kelompok dengan teknik Johari Window sebagai media dalam upaya membimbing remaja yang memerlukan dengan memanfaatkan dinamika kelompok untuk mencapai tujuan bersama dengan layanan bimbingan kelompok, remaja dapat memahami 
dirinya dengan sudut pandang dirinya maupun sudut pandang orang lain yang dapat membantu remaja tersebut memahami dirinya dari apa yang tidak diketahui oleh dirinya. Layanan bimbingan kelompok dengan teknik Johari Window memiliki tujuan membantu remaja untuk memahami dirinya dan mengaktualisasikan dirinya secara optimal.

Tujuan dalam penelitian ini untuk mendeskripsikan tingkat pemahaman diri remaja sebelum dan sesudah diberikan treatment, serta untuk mendeskripsikan ada atau tidak ada pengaruh layang bimbingan kelompok dengan teknik Johari Window terhadap pemahaman diri remaja Islam Masjid Darul Hikmah di Kelurahan Cempaka Permai.

Menurut Csikszentimihalyi \& Larson (dalam Sarwono, 2013:13), pada masa remaja dapat terjadi "restrukturisasi kesadaran". Sesuai dengan pendapat Mappiare (1982:12), remaja perlu mendapat pendidikkan yang beda karena remaja merupakan kelompok manusia yang penuh potensi. Menurut Santrock (1990:4), pemahaman diri adalah reprentasi kognitif remaja mengenai diri, substansi dan isi dari konsepsi-diri remaja. Harter (dalam Santrock, 2007:178), mengemukakan bahwa pemahaman diri seorang remaja didasarkan pada berbagai peran dan jenis keanggotaan yang mereka ikuti.

Disimpulkan bahwa pemahaman diri remaja adalah cara remaja untuk mengidentifikasi dan mengeksplorasi kemampuan, kelebihan dan kekurangan, minat dan bakat, sikap dan perilaku yang terdapat pada diri remaja tersebut secara mandiri, serta dapat menggambarkan dirinya dalam aspek fisik, psiksi, sosial maupun moral secara kompleks.

Prayitno (1995:178) menjelaskan bahwa bimbingan kelompok adalah suatu kegiatan yang dilakukan oleh sekelompok orang dengan memanfaatkan dinamika kelompok. Hartinah (2009:12) menyatakan bahwa layanan bimbingan kelompok merupakan salah satu bentuk usaha pemberian bantuan kepada orang-orang yang mengalami masalah. Sependapat dengan pendapat Tohirin (2015:164), layanan bimbingan kelompok merupakan suatu cara memberikan bantuan (bimbingan) kepada individu (siswa) melalui kegiatan kelompok.

Disimpulkan bahwa layanan bimbingan kelompok adalah kegiatan bimbingan yang dilakukan oleh Konselor/Guru Bimbingan dan Konseling secara berkelompok yang membahas permasalahan/isu yang hangat di lingkungan masyarakat atau sekolah, juga bisa membahas hal yang sudah ditentukan oleh Konselor/Guru Bimbingan dan Konseling yang bertindak sebagai pimpinan kelompok.

\section{Metode Penelitian}


Metode penelitian yang digunakan adalah penelitian eksperimen, desain dalam penelitian ini adalah eksperimen jenis one group pre-test - post-test design karena penelitian ini tidak menggunakan kelompok pembanding. Penelitian eksperimen adalah penelitian dimana ada perlakuan terhadap variable dependen (dalam Smith, 2011:29). Pengukuran yang pertama dilakukan sebelum layanan bimbingan kelompok dengan teknik Johari Window diberikan dan pengukuran kedua dilakukan setelah layanan bimbingan kelompok dengan teknik Johari Window diberikan kepada subjek penelitian.

Subjek dalam penelitian ini berjumlah 20 remaja Islam masjid Darul Hikmah yang merupakan populasi, namun yang akan diberikan perlakuan hanya 8 remaja Islam masjid Darul Hikmah yang memiliki pemahaman diri remaja yang rendah maupun sangat rendah.

Prosedur pengambilan subjek penelitian ini menggunakan teknik purposive sampling. Hal ini sesuai dengan pendapat Zuriah (2009:141), teknik purposive sampling ini berorientasi kepada pemilihan sampel di mana populasi dan tujuan yang spesifik dari penelitian, diketahui oleh peneliti sejak awal. Berdasarkan teori tersebut peneliti akan melakukan penelitian kepada remaja Islam masjid Darul Hikmah yang memiliki pemahaman diri remaja yang rendah maupun sangat rendah.

\section{Hasil dan Pembahasan}

Penelitian dilakukan dari tanggal 26 Februari 2018 sampai dengan tanggal 26 Maret 2018. Pada tanggal 03 maret 2018 dilaksanakan pre-test pada populasi yaitu 20 remaja Islam masjid Darul Hikmah, untuk mengetahui pemahaman diri remaja sebelum mendapatkan layanan bimbingan kelompok dengan teknik Johari Window sekaligus menentukan sampel.

Tabel 1

\section{Deskripsi Pre-test}

\begin{tabular}{ccl}
\hline Responden & Pre-test & \multicolumn{1}{c}{ Kategori } \\
\hline VTI & 16 & Rendah \\
\hline NN & 9 & Sangat Rendah \\
\hline TD & 15 & Rendah \\
\hline FN & 12 & Rendah \\
\hline MW & 14 & Rendah \\
\hline I & 15 & Rendah \\
\hline RUL & 16 & Rendah \\
\hline NHF & 11 & Sangat Rendah \\
\hline Rata-rata total & $\mathbf{1 3 , 5}$ & Rendah \\
\hline
\end{tabular}


Berdasarkan tabel 1, menunjukkan 8 remaja dengan tingkat pemahaman rendah dan sangat rendah tentang pemahaman diri remaja. Tingkat pemahaman remaja tentang pemahaman diri dari hasil skor pre-test rata-rata sebesar 13,5 yang masuk dalam kategori rendah. Remaja dengan tingkat pemahaman rendah dan sangat rendah tentang pemahaman diri remaja akan di berikan treatment berupa layanan bimbingan kelompok dengan teknik Johari Window.

Tabel 2

Deskripsi Post-test

\begin{tabular}{ccl}
\hline Responden & Post-test & \multicolumn{1}{c}{ Kategori } \\
\hline VTI & 25 & Sangat tinggi \\
\hline NN & 15 & Rendah \\
\hline TD & 24 & Sangat tinggi \\
\hline FN & 19 & Rata-rata \\
\hline MW & 20 & Tinggi \\
\hline I & 21 & Tinggi \\
\hline RUL & 20 & Tinggi \\
\hline NHF & 17 & Rata-rata \\
\hline Rata-rata total & $\mathbf{2 0 . 1 3}$ & Tinggi \\
\hline
\end{tabular}

Berdasarkan tabel 2, terjadi peningkatan pemahaman tentang pemahaman diri pada remaja setelah dilakukan treatment. Hasil skor post-test rata-rata sebesar 20,13 yang artinya secara keseluruhan pemahaman remaja tentang pemahaman diri masuk dalam kategori tinggi.

Hipotesis dalam penelitian ini adalah menguji pengaruh layanan bimbingan kelompok dengan teknik Johari Window untuk meningkatkan pemahaman diri remaja Islam masjid Darul Hikmah di Kelurahan Cempaka Permai, maka untuk menguji hipotesis tersebut peneliti menggunakan uji t dengan menggunakan software statistical packages for social science (SPSS) versi 23.00, dengan uji Paired Samples Test untuk melihat apakah ada pengaruh layanan bimbingan kelompok dengan teknik Johari Window untuk meningkatkan pemahaman diri remaja Islam masjid Darul Hikmah di Kelurahan Cempaka Permai.

Tabel 3

Uji Normalitas

\begin{tabular}{|c|c|c|c|}
\hline & & Pre-test & Post-test \\
\hline $\mathrm{N}$ & & 8 & 8 \\
\hline Normal Parameters ${ }^{a, b}$ & Mean & 13,50 & 20,13 \\
\hline Asymp. Sig. (2-tailed) & & $200^{\mathrm{c}, \mathrm{d}}$ & $200^{\mathrm{c}, \mathrm{d}}$ \\
\hline
\end{tabular}


Berdasarkan tabel 3, nilai signifikasi 0,200>0,05 yang berarti nilai sig. Lebih besar dari 0,05, sehingga dapat disimpulkan bahwa data berdistribusi normal.

\section{Tabel 4}

\section{Uji t}

\begin{tabular}{cc}
\hline & $\begin{array}{c}\text { Pre-test dan } \\
\text { Post-test }\end{array}$ \\
\hline T & $-11,121$ \\
\hline Sig. (2-tailed) & .000 \\
\hline
\end{tabular}

Berdasarkan tabel 4 di atas, dapat dilihat bahwa nilai t adalah -11,121 dengan signifikan 0.000. Itu berarti nilai signifikan $0.000<0.05$. Oleh karena itu dapat disimpulkan bahwa ada peningkatan skor, sehingga terdapat perbedaan sebelum dan sesudah pemberian layanan bimbingan kelompok dengan teknik Johari Window.

Pelaksanaan layanan bimbingan kelompok menggunakan teknik Johari Windowyang sudah dilakukan pada remaja Islam masjid Darul Hikmah yang berjumlah 8 remaja ini adalah tentang pemahaman diri remaja. Hal ini sangat penting dalam mengaktualisasikan diri remaja secara optimal, dengan memahami dirinya sendiri remaja akan mudah untuk mengetahui kelebihan dan kekurangan dirinya dari sudut pandang dirinya maupun orang lain. Sesuai dengan pendapat Mappiare (1982:12) remaja perlu mendapat pendidikkan yang beda karena remaja merupakan kelompok manusia yang penuh potensi. Oleh karena itu dalam memahami dirinya dan memaksimalkan potensi yang ada pada dirinya remaja membutuhkan orang lain yang dapat memberikan pandangan mengenai kelebihan maupun kekurangan yang tidak diketahui maupun yang tidak disadari oleh diri remaja tersebut. Sukardi (1990:4) menyatakan bahwa pemahaman diri dapat diartikan sebagai suatu keadaan di mana individu dapat secara mandiri mengenal berbagai aspek mengenai dirinya dengan jelas secara nalar dan logis.

Menurut Abidin (2011:134), perilaku asertif adalah seberapa sering remaja mampu mengekspresikan pikiran, perasaan dan keinginan secara tepat, jujur, terbuka, bertanggung jawab, langsung mengarah ke tujuan, penuh percaya diri dan teguh pada pendiriannya tanpa adanya perasaan cemas terhadap orang lain, tanpa mengesampingkan dan menyakiti orang lain dan tanpa melanggar hak-hak orang lain. Remaja yang mampu memahami dirinya akan berpotensi berperilaku asertif, sedangkan remaja yang tidak mampu memahami dirinya akan berpotensi berperilaku menyimpang. Kartono (2014:6) mengemukakan mengenai kenakalan remaja merupakan gejala sakit (patologis) secara sosial pada anak-anak dan remaja yang disebabkan oleh satu bentuk tingkah-laku yang menyimpang. 
Pemahaman remaja Islam masjid Darul Hikmah tentang dirinya sendiri sebelum diberikan layanan bimbingan kelompok menggunakan teknik Johari Window sama sekali tidak dapat memahami dirinya sendiri, tidak mengenali potensi yang dimilikinya dan juga tidak percaya terhadap dirinya sendiri serta melakukan tindakan yang dapat menghambat potensi yang dimilikinya seperti : tindakan yang tidak peduli dengan lingkungan sekitar, menarik diri dari lingkungan sekitar, tidak mau mendengarkan nasehat dari orang yang lebih tua darinya.

Terhitung dari pertemuan pertama sampai pertemuan kelima menunjukkan bahwa anggota bimbingan kelompok mendapatkan pengertian dan pemahaman terhadap dirinya sendiri. Anggota bimbingan kelompok menunjukkan perubahan sikap dan perilaku pada setiap proses kegiatan layanan bimbingan kelompok dan ketika berperilaku di luar kegiatan bimbingan kelompok. Menurut Hurlock (1980:209), tugas perkembangan pada masa remaja perlu di pusatkan pada penanggulangan sikap dan pola perilaku kekanak-kanakan dan mengadakan persiapan untuk menghadapi masa dewasa. Anggota kelompok sudah dapat menerapkan hasil pemahamannya dalam suatu perilaku yang dimunculkan pada saat proses kegiatan layanan bimbingan kelompok pada setiap pertemuan setelahnya. Diharapkan perubahan perilaku yang positif tersebut dapat selalu diterapkan dalam lingkungan sosial yang lebih luas, baik dalam keluarga, sekolah maupun dalam masyarakat.

Daradjat (dalam Mappiare, 1982:48), di antara hal yang kurang menyenangkan bagi remaja adalah adanya beberapa bagian tubuh yang sangat cepat pertumbuhannya, sehingga mendahului bagian lain, yaitu kaki; tangan dan hidung yang mengakibatkan cemasnya remaja melihat wajah dan tubuhnya yang kurang bagus itu.Hurlock (1980:211) mengemukakan bahwa beberapa keprihatinan akan tubuh yang dihadapi remaja merupakan lanjutan dari berbagai keprihatinan diri yang dialami pada masa remaja. Sesuai dengan pendapat ahli di atas bahwa anggota kelompok dari remaja Islam masjid Darul Hikmah menunjukkan perubahan sikap dan perilaku yang positif yang pada awalnya ada anggota kelompok MW dan FN yang cemas terhadap pertumbuhan tubuh yang tidak sesuai dengan keinginan idealnya. Namun, setelah diadakannya kegiatan layanan bimbingan kelompok MW dan FN menunjukkan perubahan kearah yang lebih baik dari setiap pertemuan kegiatan layanan bimbingan kelompok menggunakan teknik Johari Window dalam menerima bentuk tubuh yang dimilikinya sekarang dikarenakan adanya masukan dan motivasi dari anggota kelompok lain dan pemimpin kelompok bahwa bentuk tubuh yang tidak ideal bukanlah sebuah hal buruk yang menjadi penghambat aktualisasi diri secara optimal. 
Menurut Mappiare (1982:57), pertumbuhan otak dan perkembangan kemampuan pikir remaja memang berimplikasi terhadap praktik pendidikan di sekolah, pengajaran dan bimbingan. Mappiare (1982:58) menyatakan bahwa timbulnya sikap, perasaan/emosi itu (positif atau negatif) merupakan produk pengamatan dari pengalaman individu secara unik dengan benda-benda fisik di lingkungannya, dengan orang-tua, saudara-saudara, dan pergaulan sosial yang lebih luas. Hurlock (1980:207) mengemukakan mengenai perubahan emosi biasanya terjadi lebih cepat selama masa awal remaja, maka meningginya emosi lebih menonjol pada masa awal periode akhir masa remaja. Mappiare (1982:63), menjelaskan bentuk-bentuk minat atau cita-cita para remaja awal sangat beragam bentuknya, antara lain : Minat pribadi dan sosial, minat terhadap rekreasi, minat terhadap agama, minat/cita-cita pendidikan dan jabatan. Hurlock (1980:208) mengemukakan bahwa remaja melihat dirinya sendiri dan orang lain sebagaimana yang remaja tersebut inginkan dan bukan sebagaimana adanya, terlebih dalam hal cita-cita. Sesuai dengan pendapat ahli di atas bahwa anggota kelompok dari remaja Islam masjid Darul Hikmah menunjukkan perubahan sikap dan perilaku yang positif yang pada awalnya ada anggota kelompok yang tidak dapat mengontrol emosinya dan ragu-ragu terhadap pemilihan minat dan bakat yang berbeda dengan pandangan orang tua-nya. Namun, setelah diadakannya kegiatan layanan bimbingan kelompok menggunakan teknik Johari Window anggota kelompok dapat mengontrol emosinya dengan baik serta menentukan arah minat dan bakat yang dimilikinya sesuai dengan apa yang menjadi tujuan dan keinginannya tanpa harus melawan maupun menentang orang tua-nya dikarenakan adanya arahan dari pemimpin kelompok dan anggota kelompok lainnya memberikan saran dan masukan yang positif.

Mappiare (1982:69), menjelaskan bahwa situasi-situasi sosial dan moral remaja awal berkembang melalui hubungan sosial. Ruble, dkk.(dalam Santrock, 2007:180), berpendapat bahwa dibandingkan anak-anak, remaja memiliki kecenderungan lebih besar untuk melakukan perbandingan sosial ketika mengevaluasi dirinya. Sesuai dengan pendapat ahli di atas bahwa anggota kelompok dari remaja Islam masjid Darul Hikmah menunjukkan perubahan sikap dan perilaku yang positif yang pada awalnya ada anggota kelompok yang tidak percaya diri terhadap pendapat yang dimilikinya, sehingga membuatnya menjadi tidak berani memberikan pendapat dikarenakan takut dicemooh maupun disalahkan oleh anggota kelompok lainnya. Namun, ketika diadakannya kegiatan layanan bimbingan kelompok menggunakan teknik Johari Window anggota kelompok tersebut percaya diri untuk memberikan pendapat yang dimilikinya dan anggota kelompok lainnya menghargai pendapat 
tersebut dikarenakan adanya dorongan dari pemimpin kelompok kepada seluruh anggota kelompok untuk berani berpendapat tanpa takut disalahkan oleh anggota kelompok lainnya.

Mappiare (1982:69), menjelaskan bahwa situasi-situasi sosial dan moral remaja awal berkembang melalui hubungan sosial. Menurut Hurlock (1980:207), remaja menginginkan dan menuntut kebebasan, tetapi mereka sering takut bertanggung jawab akan akibatnya dan meragukan kemampuannya untuk dapat mengatasi tanggung jawab tersebut. Sesuai dengan pendapat ahli di atas bahwa anggota kelompok dari remaja Islam masjid Darul Hikmah menunjukkan perubahan sikap dan perilaku yang positif yang pada awalnya ada anggota kelompok yang saling menghina kekurangan anggota kelompok lainnya tanpa mempedulikan sakit hati yang dialami anggota kelompok tersebut. Namun, ketika diadakannya kegiatan layanan bimbingan kelompok menggunakan teknik Johari Window anggota kelompok tersebut tidak saling menghina dan menghormati satu sama lainnya dikarenakan pemimpin kelompok selalu menegaskan asas-asas layanan bimbingan kelompok disetiap pertemuan kegiatan layanan bimbingan kelompok dan mengarahkan anggota kelompok agar selalu berkata baik pada orang disekitarnya.

\section{Kesimpulan}

Hasil tes pemahaman diri remaja sebelum menerima treatment memiliki kategori skor rata-rata, yaitu 13,50 masuk dalam kategori rendah. Sedangkan, setelah diberikan treatment kategori skor rata-rata, yaitu 20,13 masuk dalam kategori tinggi. Berdasarkan hasil analisis data dapat disimpulkan bahwa layanan bimbingan kelompok dengan teknik Johari Window dapat meningkatkan pemahaman diri remaja Islam Masjid Darul Hikmah di Kelurahan Cempaka Permai, dikarenakan nilai signifikansi kurang dari 0,05 $(0,000<0,05)$.

Saran bagi remaja sebaiknya selalu mengembangkan pengetahuan mengenai pemahaman diri remaja sehinggat dapat menambah pemahaman dan pengetahuan yang telah didapat. Bagi guru pembimbing dapat melakukan layanan bimbingan kelompok untuk meningkatkan pemahaman remaja mengenai pemahaman diri remaja dikarenakan melalui layanan bimbingan kelompok remaja dapat menyerap pengetahuan dengan baik. Bagi masyarakat dapat menggunakan hasil penelitian ini sebagai bahan untuk memberi informasi, pengetahuan dan pemahaman tentang pemahaman diri remaja kepada remaja yang tidak mendapat layanan bimbingan kelompok.

\section{Daftar Pustaka}

Abidin, Z. 2011. Pamator. Jurnal Psikologi, 4(2), 129-136. 
Hartinah, S. 2009. Konsep Dasar Bimbingan Kelompok. Bandung: Refika Aditama.

Hurlock, E. B. 1980. Psikologi Perkembangan (Suatu Pendekatan Sepanjang Rentang Kehidupan). Jakarta: Erlangga

Kartono, K. 2014. Patologi Sosial 2 Kenakalan Remaja. Jakarta : RajaGrafindoPersada

Mappiare, A. 1982. Psikologi Remaja. Surabaya : Usaha Nasional.

Prayitno. 1995. Layanan Bimbingan dan Konseling Kelompok (Dasar dan Profil). Jakarta : Ghalia Indonesia.

Santrock, J. W. 2007. Remaja. Jakarta : Erlangga.

Sarjono, H., Julianita, W. 2013. SPPS vs LISREL Sebuah Pengantar, Aplikasi untuk Riset. Jakarta : Salemba Empat.

Sarwono, S. W. 2013. Psikologi Remaja. Jakarta: Raja Grafindo Persada.

Smith, M. Bin. 2011. PengaruhLayananKonselingKelompokterhadapDisiplinBelajarSiswa di SMA Negeri 1 AtinggolaKabupatenGorontalo Utara.JurnalPenelitiandanPendidikan, $8(1), 22-32$.

Sukardi, D. K. 1990. Analisis Tes Psikologis. Rineka Cipta

Tohirin. 2015. Bimbingan dan Konseling di Sekolah dan Madrasah (Berbasis Integrasi). Jakarta: PT Raja Grafindo Persada.

Zuriah, N. 2009. Metodologi Penelitian Sosial dan Pendidikan. Jakarta:Bumi Aksara. 